Cytogenet Genome Res 1985;39:I-VI

\title{
Contents, Vol. 39, 1985
}

\section{Original Articles}

In vitro growth and chromosome constitution of placental cells.

I. Spontaneous and elective abortions

Hunt, P.A.; Jacobs, P.A

In vitro growth and chromosome constitution of placental cells.

II. Hydatidiform moles

Hunt, P.A.; Jacobs, P.A

Identification of sex chromosomes in lake trout (Salvelinus

namaycush)

Phillips, R.B.; Ihssen, P.E................................................ 14

Meiotic association between the

paired autosomal elements as a

Rosenmann, A.; Wahrman, J.;

Correlation between sexual phenotype and $\mathrm{X}$-chromosome

inactivation pattern in the $\mathrm{X}^{*} \mathrm{XY}$ wood lemming

Schempp, W.; Wiberg, U.; Fredga, K.

Comparative chromosome analysis of nine squamous cell car cinoma lines from tumors of the head and neck

Hauser-Urfer, I.H.; Stauffer, J ............................................... 35

G-banding evidence for a conserved complement in the Marsu-

pialia

Rofe, R.; Hayman, D

Cell surface differentiation antigen of human muscle encoded by a gene (MIC 12) on chromosome 15 Walsh, F.S.; Quinn, C.A.;

Pym, B.; Goodfellow, P.N. ... 51

The Chinese hamster Don cell line differs from normal diploidy

by one chromosome band

Chen, T.R.

\section{Brief Reports}

Bilateral nephroblastoma associated with a 3;17 translocation Soulie, J.; Rousseau-Merck, M.-F.; Mouly, H.; Nezelof, C. 64 Assignment of the human antithrombin III structural gene to chromosome lq23-25

Bock, S.C.; Harris, J.F.; Balazs, I.; Trent, J.M.

Chromosome banding techniques for morphologically classi

fied cells (with 1 color plate)

Knuutila, S.; Keinänen, M

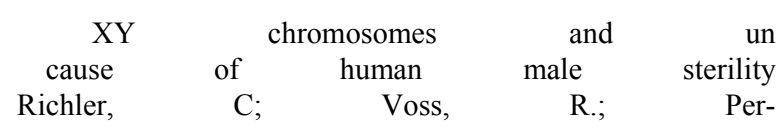
19

Induction of chromosome banding by trypsin/EDTA for gene mapping by in situ hybridization Popescu, N.C.; Amsbaugh, S.C.;

Swan, D.C.; DiPaolo, J.A. 73

The G-banded chromosomes of Roosevelt's muntjac, Muntia-

cus rooseveltorum

Wurster-Hill, D.H.; Seidel, B... 
A viable calf with trisomy 22

Mayr, B.; Krutzler, H.; Auer, H.; Schleger, W.; Sasshofer, K.;

Glawischnig, E. 77

\section{Commentary}

$\mathrm{X}$ chromosome rearrangements and leukemia Werner-Favre, C; Beris, P.; Engel, E. . . .

No. 2

\section{Original Articles}

Synaptonemal complex analysis of a pericentric inversion in chromosome 2 of domestic fowl, Gallus domesticus

Kaelbling, M.; Fechheimer, N.S 82

Localization of glucose-6-phosphate dehydrogenase in mouse and man by in situ hybridization: evidence for a single locus and transposition of homologous X-linked genes

Martin-DeLeon, P.A.; Wolf, S.F.; Persico, G.; Toniolo, D.;

Martini, G.; Migeon, B.R

Cytogenetic demonstration of out-of-phase DNA synthesis in endoreduplicated $\mathrm{CHO}$ cells: evidence for partial endoreduplication

Takanari, H.; Nakakuki, K.; Izutsu, K

Chromosomal phylogeny of Lagothrix, Brachyteles, and Caca-

jao

Viegas Péquignot, E.; Koiffmann, C.P.; Dutrillaux, B. . 99 Different sister chromatid exchange rates in XX and XY cells of a pair of human chimeric twins

Wulf, H.C.; Niebuhr, E 105

Human metallothionein-II processed gene is located in region

p $11 \rightarrow$ q21 of chromosome 4

Lieberman, H.B.; Rabin, M.; Barker, P.E.; Ruddle, F.H.;

Varshney, U.; Gedamu, L

Contents

III

Chromosomal site of hepatitis B virus (HBV) integration in a human hepatocellular carcinoma-derived cell line Simon, D.; Searls, D.B.; Cao, Y.; Sun, K.; Knowles, B.B. . 116

More precise localization of the human Factor IX gene by in situ hybridization

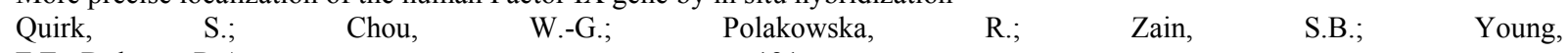

F.E.; Doherty, R.A ……………………..................................... 12

Quantitation of the transgenome size in chromosome-mediated gene transfer lines

Murphy, P.D.; Miller, C.L.; Ruddle, F.H.

Equivalence of nucleolar organizer activity among primate species

Quirk, S.; Henderson, A.S

The high-resolution RBA-banding pattern of bovine chromo

somes

Di Berardino, D.; Iannuzzi, L.; Lioi, M.B 
Regional mapping of $c K i$-ras proto-oncogene on mouse chro mosome 6 by in situ hybridization

Cahilly, L.A.; George, D.L

Characterization of G-banded chromosomes of the Indian

muntjac and progression of banding patterns through differ

ent stages of condensation

Sen, P.; Sharma, T

\section{Brief Reports}

The thyroglobulin gene resides on chromosome 8 in man and on chromosome 7 in the rat

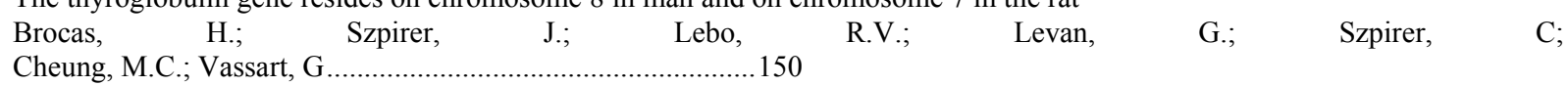
... 150

Hybridization with human cells corrects the elevated SCE fre quency and BrdU hypersensitivity of hamster cell line

EM9

Ray, J.H.; Louie, E.; German, J ......

\section{Genetic Linkage Data}

Linkage relationships of the gene for the $\beta$ subunit of nerve growth factor $(N G F B)$ with other chromosome 1 marker loci Darby, J.K.; ICidd, J.R.; Pakstis, A.J.; Sparkes, R.S.; Cann, H.M.; Ferrell, R.E.; Gerhard, D.G.; Riccardi, V.; Egeland, J. A.; Shooter, E.M.; Cavalli-Sforza, L.L.; Kidd, K.K. ... 158

No. 3

\section{Original Articles}

Preferential nondisjunction of specific bivalents in oocytes from Djungarian hamsters (Phodopus sungorus) following colchicine treatment

Hummler, E.; Hansmann, 1

Breakage on chromosome 2 brings the Ck gene to a region 3' of

$c-m y c$ in a Burkitt's lymphoma line carrying a $(2 ; 8)$ translocation

Malcolm, S.; Davis, M.; Rabbitts, T.H

In situ hybridization and translocation breakpoint mapping.

II. Two unusual $t(21 ; 22)$ translocations

Cannizzaro, L.A.; Aronson, M.M.; Emanuel, B.S

In situ hybridization and translocation breakpoint mapping.

III. DiGeorge syndrome with partial monosomy of chromo some 22

Cannizzaro, L.A.; Emanuel, B.S

Detection of $\mathrm{Y}$-specific repeat sequences in normal and variant human chromosomes using in situ hybridization with biotinylated probes

Lau, Y.-F

Studies on endoreduplication. V. A three-dimensional scheme for diplo- and quadruple chromosomes and a model for

DNA replication

Takanari, $\mathrm{H}$

Chromosomal evolution in Malagasy lemurs. VIII. Chromo some banding studies of Lepilemur ruficaudatus, L. leucopus, and L. septentrionalis

Rumpler, Y.; Ishak, B.; Warter, S.; Dutrillaux, B 194

Chromosome mapping of genes on the short arm of human chromosome 11: parathyroid hormone gene is at 11 pi5 together with the genes for insulin, c-Harvey-ras 1, and B-hemoglobin Zabel, B.U.; Kronenberg, H.M.; Bell, G.I.; Shows, T.B. . 200 
Assignment of the porcine major histocompatibility complex to chromosome 7 by in situ hybridization

Rabin, M.; Fries, R.; Singer, D.; Ruddle, F.H 206

Correlation between $\mathrm{X}$-chromosome inactivation and cell dif

ferentiation in female preimplantation mouse embryos

Sugawara, O.; Takagi, N.; Sasaki, M

Localization of the $\alpha$ and $\beta$ casein genes to the q24 region of chromosome 12 in the rabbit (Oryctolagus cuniculus L.) by in situ hybridization

Gellin, J.; Echard, G.; Yerle, M.; Dalens, M.; Chevalet, C;

Gillois, M...

Assignment of uroporphyrinogen decarboxylase (UROD) to the

pter $\rightarrow$ p21 region of human chromosome 1

McLellan, T.; Pryor, M.A.; Kushner, J.P.; Eddy, R.L.;

Shows, T.B

\section{Brief Reports}

Effects of the male contraceptive agent gossypol on meiotic chromosomes of the male rat

Bhagirath, Th.; Kundu, S.C .

The structural gene for human coagulation factor $\mathrm{X}$ is located

on chromosome $13 \mathrm{q} 34$

Scambler, P.J.; Williamson, R .

Alterations in the time of $X$ chromosome replication induced

by 5 -azacytidine in a patient with $48, \mathrm{XXXY} / 47, \mathrm{XXY}$

Gregory, P.; Greene, C; Shapira, E.; Wang, N.

\section{Commentary}

Familial reciprocal translocation $\mathrm{t}(1 ; 4)(\mathrm{q} 31 ; \mathrm{p} 15)$ traced through five generations Martin-Lucas, M.A.; Perez-Castillo, A.; Abrisqueta, J.A. . 237

\section{Genetic Linkage Data}

Cystic fibrosis: analysis of linkage of the disease locus to red cell and plasma protein markers Tsui, L.-C; Cox, D.W.; McAlpine, P.J.; Buchwald, M. . . 238

Announcements 240

IV

Contents

No. 4

\section{Original Articles}

Shiverer gene maps near the distal end of chromosome 18 in the house mouse

Sidman, R.L.; Conover, C.S.; Carson, J.H

Localization of the human myelin basic protein gene $(M B P)$ to

region $18 \mathrm{q} 22 \rightarrow \mathrm{qter}$ by in situ hybridization

Saxe, D.F.; Takahashi, N.; Hood, L.; Simon, M.I

Normal disjunction in Robertsonian heterozygotes from a

highly polymorphic lizard population

Porter, C.A.; Sites, J.W., Jr

Major chromosome homeologies between Muridae and Cri-cetidae

Viegas-Péquignot, E.; Kasahara, S.; Yassuda, Y.; Dutril-

laux, B

Isolation and characterization of two repetitive DNA fragments located near the centromere of the mouse X chromosome

Disteche, CM.; Tantravahi, U.; Gandy, S.; Eisenhard, M.;

Adler, D.; Kunkel, L.M. 
High-resolution chromosomal localization of the $\beta$-gene of the human B-globin gene complex by in situ hybridization

Lin, C.C.; Draper, P.N.; De Braekeleer, M

Aging and aneuploidy: evidence for the preferential involve

ment of the inactive $\mathrm{X}$ chromosome

Abruzzo, M.A.; Mayer, M.; Jacobs, P.A

Localization of the human salivary protein complex (SPC) to

chromosome band $12 \mathrm{pl} 3.2$

Mamula, P.W.; Heerema, N.A.; Palmer, C.G.; Lyons,

K.M.; Karn, R.C

Gene mapping in the Chinese hamster and conservation of

syntenic groups and Q-band homologies between Chinese

hamster and mouse chromosomes

Satoh, H.; Yoshida, M.C

\section{Brief Reports}

Double synchronization of human lymphocyte cultures: selec

tion for high-resolution banded metaphases in the first and

second division

Rønne, M.

Regional assignments of eight genes on chromosome 2 in the American mink

Zhdanova, N.S.; Gradov, A.A.; Rubtsov, N.B.; Pack, S.D.;

Serov, O.L

\section{Genetic Linkage Data}

Cystic fibrosis: progress in mapping the disease locus using polymorphic DNA markers. I.

Tsui, L.-C; Zsiga, M.; Kennedy, D.; Plavsic, N.; Markie-

wicz, D.; Buchwald, M

Author Index

Subject Index

...303

S. Karger $\square$ Medical and Scientific Publishers $\cdot$ Basel $\cdot$ München $\cdot$ Paris $\square$ London $\cdot$ New York $\cdot$ New Delhi $\bullet$ Singapore $\bullet$ Tokyo $\cdot$ Sydney

Drug Dosage

The authors and the publisher have exerted every effort to ensure that drug selection and dosage set forth in this text are in accord with current recommendations and practice at the time of publication. However, in view of ongoing research, changes in government regulations, and the constant flow of information relating to drug therapy and drug reactions, the reader is urged to check the package insert for each drug for any change in indications and dosage and for added warnings and precautions. This is particularly important when the recommended agent is a new and/or infrequently employed drug. 
All rights reserved.

No part of this publication may be translated into other languages, reproduced or utilized in any form or by any means, electronic or mechanical, including photocopying, recording, microcopying, or by any information storage and retrieval system, without permission in writing from the publisher or, in the case of photocopying, direct payment of a specified fee to the Copyright Clearance Center (see 'Information for Readers and Subscribers')

C Copyright 1985 by S. Karger AG, P.O. Box, CH- 4009 Basel (Switzerland) Printed in Switzerland by Buchdruckerei Schüler AG, Biel Knuutila Keinänen

Plate I

Fig 1. Pokeweed-mitogen-stimulated lymphocytes prepared by the method described in this report. To identify B cells, antibody to human B cells and conjugation with tetramethylrhodamine (TRITC) were used, (a) Two mitotic cells, with the lower one (a B cell) positive for TRITC. (b) The same two cells stained with Hoechst 33258. (c) The same cells after G banding.

Fig 2. SCE-stained mitotic chromosomes within an intact cell membrane. 
Cytogenet. Cell Genet, Vol. 39

S. Karger, Basel 